\title{
KONFLIK TANAH DI TENGAH PEMBANGUNAN
}

\author{
Josef Purnama Widyatmadja ${ }^{1}$
}

\begin{abstract}
"Economic development is a necessity in a nation longing for progress. But often the building also had its negative effects are not small. One of the adverse effects of development is the horizontal conflict due to land issues. Tension between economic interests with the interests of the people. It is often injured sense of justice. There were changes in the ownership status of previously communal land into private property. Weak community then became lost their land due to the construction process. The author tries to explain the issue of this land and give his view of how development should be implemented for the benefit of the people, especially the weak are not neglected".
\end{abstract}

Kata-kata kunci : Pembangunan, Konflik Tanah, Keadilan, Kepentingan Rakyat, Ekonomi.

"Allah menciptakan taman Eden untuk didiami dan dipelihara, tetapi manusia menjarah dan memerasnya untuk mengumbar keserakahan". Pdt. Josef Purnama Widyatmadja adalah direktur Center for Development and Culture Surakarta.
Alamat emailnya jwidytmadja@gmail.com Phone/wa 081360248845. Makalah ini di sampaikan di Sekolah Tinggi Teologi Abdiel Ungaran Semarang tanggal 10 April 2017. 


\section{PENDAHULUAN :}

\section{PEMBANGUNAN MENYEBABKAN LAPAR TANAH}

Dembangunan yang berorientasi pada pertumbuhan ekonomi dan ekspor
telah menyebabkan penyakit lapar tanah (land hunger) di mana-mana. Hal itu ditulis oleh Dr. Loekman Soetrisno dari UGM dalam Suara Pembaruan (21/11/1993). Pembangunan megaproyek, seperti pembangunan waduk, hotel wisata, jalan tol, pabrik dan perkebunan, tidak saja menelan anggaran belanja negara yang sangat besar, tetapi juga melahap tanah rakyat secara paksa. Dalam praktek sering di jumpai rakyat di paksa menyerahkan tanahnya dengan harga murah kepada negara atau perusahaan. Aparat pemerintah lebih memihak para pengusaha daripada rakyat sebagai pemilik. Perlawanan petani di Tulang Bawang Lampung kepada PT BNIL yang gencar dimuat di media merupakan perlawanan atas kerakusan tanah oleh pemilik modal yaitu "empire" yang di dukung oleh aparat. Tidak jarang perlawanan para petani untuk mempertahankan tanah pusaka mereka ditindas dan di fitnah. Mereka sering disebut sebagai pengacau keamanan dan anti-pembangunan. Para pendamping petani yang jadi korban pembangunan sering dituduh sebagai provokator dan dikriminalisasi seperti yang dialami pendeta Sugijanto dan guru ngaji Rajiman di Tulang Bawang Lampung.

\section{TANAH SEBAGAI IBU PERTIWI}

Bumi dan alam semesta diciptakan untuk kesejahteraan seluruh makhluk, bukan untuk mengumbar ketamakan segelintir orang. Manusia bukanlah pemilik atas tanah dan bumi, tetapi sebagai pengelola/steward (Kejadian 1, 2; Mazmur 24:1). Hasil tanah tidak dimaksudkan untuk mencukupi ketamakan seseorang, tetapi untuk menghidupi banyak orang. Pada zaman dahulu tanah adalah milik masyarakat komunal dan bukan milik pribadi yang bisa diperdagangkan. Dalam Alkitab dan tradisi suku-suku, tanah tidak bisa di jual belikan. Itulah sebabnya mengapa Nabot menolak menjual tanahnya kepada Raja Achab untuk dijadikan kebun sayur ( I Raja 21 ). Pada masyarakat primitif, menurut Emil de Levelleye, penggunaan tanah dan hasilnya digilir secara periodik (Avila, 1983:6).

Tanah menurut kepercayaan kuno bukan sekedar memiliki makna ekonomi, tetapi juga makna sosial, kultural dan spiritual. Tanah tumpah darah bisa juga 
disebut ibu pertiwi/tanah pusaka, karena tidak tidak sekedar dihuni oleh orang yang masih hidup tetapi juga roh dan jasad orang yang sudah mati (Kejadian 49:29-32; Bilangan 26:52-55). Tanah sebagai ibu dari manusia karena manusia di ciptakan dari tanah.

\section{PERUBAHAN STATUS TANAH}

Desmond Tutu pemenang hadiah noble untuk perdamaian berkata:

"Ketika orang Eropa datang ke Afrika mereka punya Alkitab dan kami punya tanah.

Mereka mengajak kami memejamkan mata dan berdoa bersama.

Selesai berdoa kami punya Alkitab dan orang Eropa punya tanah kami."

Perkembangan masyarakat sering disertai perubahan status tanah. Perubahan status tanah bisa terjadi karena:

Penjajahan dan pendudukan

Penjualan tanah sebagai komoditi

Industrialisasi dan pembangunan pemukiman dan infrastruktur.

Ketika ada ekspansi dan kolonisasi satu negara/bangsa terhadap bangsa lainnya, maka terjadilah perubahan status tanah. Sejak pendaratan Columbus di benua Amerika dan Vasco Da Gama di Afrika, kepemilikan tanah penduduk setempat bergeser ke tangan pendatang/penjajah. Status kepemilikan tanah bergeser dari milik bersama masyarakat setempat menjadi milik pribadi para penjajah. Hukum adat sering dibatalkan dan diganti dengan hukum agraria yang dibuat oleh penguasa baru. Akibatnya tanah tidak lagi sebagai ciptaan Tuhan untuk dipelihara dan sebagai sumber hidup tapi telah berubah sebagai komoditi untuk dieksploitasi.

\section{TANAH BUDAK DAN TENTARA}

Perubahan status tanah sebagai milik pribadi telah mengubah pranata sosial. Para penguasa baru tidak mungkin menggarap tanahnya dengan tangannya 
sendiri. Mereka membutuhkan budak-budak sebagai tenaga kerja untuk menggarap tanah mereka. Itulah sebabnya setelah pendaratan Colombus di Amerika, para penjarah tanah di Amerika mendatangkan budak dari Afrika untuk menggarap tanah mereka. Makin luas tanah yang dimiliki oleh tuan tanah, makin banyak budak yang dibutuhkannya.

Dengan sistim perbudakan dan kepemilikan tanah, para budak akan tetap miskin dan pemilik tanah makin kaya. Untuk menjaga keselamatan tanah dan harta serta keselamatan mereka, maka para tuan tanah membutuhkan aparat keamanan berupa tentara dan polisi. Melalui polisi dan tentara inilah para pemilik tanah menegakkan hukum dan keamanan. Akibatnya, masyarakat terbagi atas tiga lapisan, yaitu: pertama, para tuan tanah pemilik modal (empire), kedua, tentara; dan ketiga, rakyat jelata, yaitu para budak.

Tugas tentara adalah mengamankan keselamatan harta dan jiwa para bangsawan dari ancaman pemberontakan para budak. Kita bisa mengambil contoh ketika kejayaan Romawi terjadi pemberontakan budak oleh Spartacus. Kejayaan Romawi atas negara-negara tetangga telah menimbulkan perkembangan masyarakat sebagai berikut:

Timbulnya tentara bayaran dan tenaga ahli (teknokrat, seniman dan lain sebagainya).

Para tuan tanah kecil kalah bersaing dengan tuan tanah besar.

Penggusuran tanah terjadi, sebab tanah mereka dibutuhkan atas nama pembangunan, baik untuk kepentingan-kepentingan publik maupun swasta.

Transmigrasi dijalankan, hukum adat diganti dengan hukum kepemilikan Romawi.

Sanksi dan hukuman bagi budak yang melawan hukum perbudakan.

Mengenakan pajak pada rakyat jajahan.

Hasil jarahan diangkut ke pusat pemerintahan. Tanam paksa komoditi tertentu untuk kepentingan pusat.

Kehidupan mewah di kota besar dan kemiskinan di desa dan negara jajahan. 
Tugas negara adalah menjaga milik pribadi (Cicero), bukan menyejahterakan rakyat.

Kepala daerah bukan dipilih oleh rakyat, tetapi dipilih oleh pusat.

\section{BAGAIMANA DENGAN INDONESIA ?}

Dalam kehidupan sehari-hari pranata sosial ini masih terasa dalam bentuk baru. Sejak kedatangan Belanda di Indonesia, hukum kepemilikan tanah secara adat sering diabaikan dan harus disesuaikan dengan hukum nasional. Sering kali hukum nasional yang dibuat bukan untuk melindungi petani tapi untuk melayani mereka yang akan investasi. Beberapa tanah di bumi pertiwi sedikit demi sedikit tapi pasti berubah menjadi milik beberapa pejabat atau warga Belanda yang bermukim di Indonesia. Kepemilikan tanah secara komunal mulai diganti menjadi kepemilikan tanah berdasarkan secarik kertas(sertifikat).

Wajah pembangunan Indonesia sejak merdeka masih melanjutkan warisan kolonial. Tatanan itu melayani "empire" bukan petani. Semboyan buruh dan petani sebagai soko guru revolusi maupun pembangunan sering disalahartikan. Buruh dan petani hanya dituntut untuk berkorban bagi revolusi dan pembangunan bukannya penerima hasil pembangunan. Sejak Orde Baru pembangunan memang membawa kemajuan ekonomi tapi sekalius membawa perubahan status tanah dan hutan di berbagai tempat di Indonesia. PT. Freeport mendapatkan konsesi di tanah Papua, PT Inco di Sulawesi Selatan dan PT BNIL di Sumatera. Akhirnya masyarakat setempat menjadi korban hukum pembangunan. Penduduk setempat sebagai pemilik tanah telah disingkirkan dan diganti dengan penguasa baru. Keputusan HPH (Hak Pengusahaan Hutan) sering lebih menguntungkan segelintir orang. Sumberdaya alam berupa tanah, hutan dan laut tidak lagi untuk kesejahteraan masyarakat setempat, sebaliknya menjadi sapi perahan untuk kerakusan para pendatang.

\section{KEADILAN AGRARIA DAN AGAMA}

Peranan agama dalam kepemilikan tanah dan perbudakan seringkali mendua. Tidak jarang agama yang diwakili para imam cenderung memihak penguasa dari pada petani. Ketidakadilan yang dilakukan para imam pada zaman 
Mesir kuno, misalnya sering mengakibatkan pemberontakan petani (Epsztein, 1983:27).

Dalam kisah Yusuf di kitab Kejadian, saat terjadi masa panen selama tujuh tahun, Yusuf berhasil membeli hasil panen para petani Mesir dan menyimpannya dalam lumbung-lumbung negara. Saat masa paceklik tujuh tahun tiba Yusuf membuka lumbung gandum untuk dijual kepada petani Mesir. Ketika para petani tidak punya lagi uang untuk membeli gandum, mereka menjual ternaknya untuk mendapatkan gandum. Selanjutnya ketika para petani tidak memiliki ternak dan sawah lagi untuk dijual sebagai ganti gandum, maka dalam Kejadian 47:18 dan 19 petani Mesir datang pada Yusuf dan berkata :: "Tidak usah kami sembunyikan bahwa setelah uang kami habis, setelah kumpulan ternak kami menjadi milik tuanku, tidaklah ada lagi yang tinggal yang dapat kami serahkan kepada tuanku selain badan kami dan tanah kami" Selanjutnya dalam ayat 19 petani berkata: “ Belilah kami dan tanah kami sebagai ganti makanan, maka kami dengan tanah kami akan menjadi hamba kepada Firaun...."

Lahirnya sistim perbudakan tidak lepas dari penguasaan tanah oleh seseorang atau kelompok orang. Pada zaman Yusuf orang Mesir tidak hanya harus menjual tanahnya kepada Firaun demi makanan, tapi juga menjual tubuhnya, kemerdekaannya untuk menjadi budak. Akhirnya seluruh tanah yang dulunya dimiliki rakyat di kuasai oleh Firaun kecuali tanah milik imam(Kejadian 47:22).

Istilah buruh migran merupakan penghalusan untuk menutupi praktek perbudakan modern dengan istilah yang lebih manusiawi. Terciptanya buruh migran karena ada tuntutan kebutuhan untuk mengelola kepemilikan tanah dan kekayaan disatu pihak serta keluarga petani yang harus menjual tubuh mereka dilain pihak. Karena tidak ada lagi tanah dan harta yang bisa mereka jual untuk mendapatkan makanan.

Kehidupan para imam Mesir mendapatkan tunjangan hidup dan kesejahteraan dari Firaun, sehingga agama telah dikooptasi oleh negara dan agama menjadi alat untuk melegitimasi kebijakan negara. Fungsi agama hanya mendoakan kepentingan Firaun bukan untuk mendengarkan jeritan petani. Para imam di Mesir menjadi tidak peka atas jeritan budak Israel karena mereka menjadi kaki tangan Firaun. Dalam kontek inilah muncul seorang bernama Musa sang pembebas budak.

Soal kepemilikan tanah, hukum Hamurabi dari Babil hampir serupa dengan hukum Musa di Israel. Di Mesopotamia dikenal pembebasan budak tiga tahun 
sekali, sedangkan di Israel tujuh tahun sekali. Di Mesopotamia juga dikenal hukum penggiliran tanah untuk para penggarap (Bandingkan dengan tahun Yobel yang diselenggarakan lima puluh tahun sekali di Israel). Tanah yang digadaikan dikembalikan pada penggarap semula atau keluarganya(Imamat 25). Bagaimana dengan Freeport yang sudah mencapai lima puluh tahun di tahun 2017 ?

Praktek tanah sebagai milik pribadi adalah menyangkali Allah sebagai pencipta dan pemilik langit dan bumi. Allah menciptakan Adam dan Hawa sebagai pemelihara-penunggu, bukan pemilik taman Eden. Manusia harus berbagi kehidupan dengan makhluk lain di taman Eden.

Iman Kristen yang bersumber dari tradisi Mesopotamia (Timur Tengah) seharusnya memperhatikan kepemilikan tanah secara komunal. Tetapi selama berabad-abad khususnya setelah era raja Konstantin Agung, Iman Kristen banyak dipengaruhi filsafat Romawi. Saat ini ajaran Kristen yang berkembang lebih mengutamakan kepemilikan pribadi berupa harta milik dan tanah serta keselamatan pribadi. "Yang penting gue di selamatkan yang lain binasa salah lu". Dalam hukum Romawi tentang kepemilikan pribadi, manusia berhak memakai, memelihara atau merusak apa yang dia miliki tanpa ada tanggung jawab terhadap lingkungan (masyarakat di sekitarnya). Tugas negara bukan menyejahterakan rakyat, tetapi melindungi kekayaan pribadi. Demikian juga agama bukan untuk memberdayakan orang miskin tapi menghukum orang kafir. Reformasi Martin Luther gagal menyentuh keadilan agraria karena ia berutang budi kepada pangeran jerman. Akibatnya ajaran Kristen yang disebarkan ke Dunia Ketiga lebih mementingkan keselamatan dan kekayaan pribadi serta mengabaikan ajaran kepemilikan komunal (common goods). Tujuan dunia diciptakan oleh Allah, bukan untuk mengumbar keserakahan konglomerat tapi mensejahterakan rakyat.

Teologi lingkungan hidup dan gerakan pelestarian alam tidak ada artinya apabila tidak dikaitkan dengan teologi taman Eden atau teologi agrarian justice. Yaitu penataan ulang kepemilikan dan pengelolaan tanah. Manusia tidak saja telah merampok taman Eden dari sesamanya, tetapi juga telah merampok taman Eden dari milik Allah. Tahun Yobel harus dilihat sebagai pertobatan komunitas seharusnya menjadi inti dari pengharapan orang percaya dalam mewujudkan agrarian (economic) and ecological justice. Keadilan ekonomi dan ekologi seharusnya menjadi inti dari pemberitaan Injil (Lukas 4:18-20; Matius 25:31-46; II Petrus 3:116; Wahyu 21). . Manusia adalah pengelola taman Eden bukan pemilik, Sebab itu tak ada hak untuk menguasai dan merusak taman Eden 


\section{PENUTUP:}

\section{PARADIGMA BARU KEMAJUAN}

Kemajuan pembangunan tidak cukup diukur dengan kenaikan GNP dan GDP tapi perlu juga memperhatikan equality (kesetaraan) dan sustainability. Meningkatnya produksi, pemakaian tehnologi harus mampu mengurangi angka kemiskinan dan kematian serta kelestarian alam. Ukuran kemajuan seharusnya, memperhatikan:

- Bukan makin banyak mobil pribadi yang beroperasi di jalan raya, tetapi kemudahan - keselamatan rakyat banyak yang menggunakan transportas masal.

- Bukan makin mewah mobil yang harus dibuat, tetapi mobil ramah lingkungan yang harus diciptakan.

- Bukan makin banyak rumah sakit mewah yang dibangun, tetapi makin banyak rakyat yang bisa disentuh pelayanan kesehatan.

- Bahwa kemajuan teknologi dan pertumbuhan ekonomi yang dicapai mampu memberi manfaat pada kesejahteraan rakyat.

Pada era abad dua puluh satu, kemiskinan dan kerusakan lingkungan makin memprihatinkan semua orang. Nasib milyaran manusia dan kerusakan alam tidak mungkin diselesaikan dengan cara pembangunan yang berorientasi pada pertumbuhan ekonomi, peningkatan ekspor, kemajuan teknologidan pendekatan keamanan semata. Dunia membutuhkan paradigma baru dalam mengukur keberhasilan pembangunan. Paradigma baru tersebut harus memperhatikan tiga hal berikut ini; Pertama, bahwa pembangunan harus berpusat pada pemberdayaan kemandirian rakyat; kedua, kelestarian lingkungan dan ketiga transformasi tatanan sosial ekonomi yang adil

Ini berarti, bahwa perwujudan agrarian justice, partisipasi rakyat, demokrasi, hak asasi manusia, keadilan bagi semua orang dan kelestarian alam harus menjadi indikator keberhasilan pembangunan.

Indikator baru dalam mengukur keberhasilan pembangunan ini dalam bahasa iman adalah jalan pertobatan. Artinya berbalik arah 180 derajad. Dari 
greedy menjadi sharing economics. Pembangunan tidak sekedar membutuhkan keamanan dan pertumbuhan ekonomi tapi juga penghormatan HAM dan kedaulatan rakyat serta pemerataan ekonomi. Tugas manusia adalah merawat dan berbagi kehidupan bagi sesama dan alam semesta.

\section{DAFTAR ACUAN}

Charles, Avila. Ownership, Early Christian Teaching, Orbis Books New York 1983

Rob, Driemmelen van. Faith in a Global Economy, WCC,Geneve 1998

Leon, Epsztein. Social Justice in the Ancient Near East and the People in the Bible,SCM Press LTD London, 1983

Justo, Gonzalez L. Faith and Wealth,Harpher and Row Publication, San Francisco, 1990

James, Robertson. Future Wealth, Cassel Publishers Limited, London,1990

Harian Suara Pembaruan, Jakarta 21 November 1993 